\title{
MODELING NO-TILL ADOPTION BY CORN AND SOYBEAN PRODUCERS: INSIGHTS INTO SUSTAINED ADOPTION
}

\author{
TARA WADE* \\ University of Florida, Southwest Florida Research and Education Center, Immokalee, Florida \\ ROGER CLAASSEN \\ U.S. Department of Agriculture, Economic Research Service, Washington, D.C.
}

\begin{abstract}
No-till acreage has increased in recent years, but many farmers alternate no-till with other tillage practices, limiting public and private benefits from sustained no-till adoption. Revealed preference data are used in an ordered logit regression analysis to determine the effect of soil characteristics, climate, regions, farm characteristics, and producer demographics on producers' choices to use continuous tillage, alternate no-till systems with tillage systems, or continuously use no-till. The model provides insight into the characteristics and conditions that are conducive to each tillage regime. The attributes found to significantly affect continuous no-till use are erodibility classification, drainage, farm size, and climate.
\end{abstract}

Keywords. ARMS, continuous no-till use, no-till, ordered logit, tillage history

JEL Classifications. Q12, Q15, Q18, Q24, Q1, Q2

\section{Introduction}

No-till crop production yields a range of soil quality and environmental benefits that can accrue to farmers and landowners, the public, or both. These benefits include less soil erosion (preservation of soil depth), reduced sediment loss to water, higher levels of soil carbon sequestration (West and Post, 2002), soil moisture conservation (perhaps reducing drought risk) (Davey and Furtan, 2008), and improved soil health. In terms of soil health, no-till can help increase

\footnotetext{
We are grateful to anonymous referees who provided valuable feedback. This research was partially funded by the U.S. Department of Agriculture (USDA), Economic Research Service cooperative agreement no. 58-6000-4-0013 and by the USDA, National Institute of Food and Agriculture, award no. 2016-6702424755. The funding source has no involvement in the study design, data collection and analysis, or any other aspects of the research or paper publication. The views expressed in this article are those of the authors and do not necessarily reflect the views or policies of the USDA.
}

*Corresponding author’s e-mail: tara.wade@ufl.edu 
soil organic matter and available water capacity and improve soil aggregate size and stability among other benefits (U.S. Department of Agriculture, Natural Resources Conservation Service [USDA-NRCS], 2015).

Many of these benefits, however, are fully realized only when no-till is used continuously over a period of years. Under no-till, for example, the soil sequesters carbon slowly over time while soil carbon gains can be undone by a single tillage operation (Johnson et al., 2005). Likewise, soil health benefits are largely a function of organic matter accumulation that happens only when no-till is practiced continuously over a period of years (USDA-NRCS, 2015). Significant gains in organic matter and related improvements in soil health are unlikely to be realized by producers who alternate no-till with other tillage practices.

No-till acreage is increasing, but many farmers alternate no-till with other tillage practices, limiting both public and private benefits. Using the Agricultural Resource Management Survey (ARMS) field-level data on production practices, Horowitz, Ebel, and Ueda (2010) found an upward trend in no-till for a number of major crops, including corn, soybeans, and wheat, during the early and mid2000s. Data collected in the 2010-2011 farm-level portion of ARMS show that no-till or strip-till was used on just under $40 \%$ of land in corn $(32 \%)$, soybeans $(46 \%)$, wheat $(43 \%)$, and cotton $(33 \%)$ (Wade, Claassen, and Wallander, 2015).

The ARMS data also show that many farms alternate no-till with other tillage practices. Field-level ARMS data for 2010 (corn) and 2012 (soybeans) provide a 4-year history of no-till use (which may include crops other than the target crop). The corn survey shows that roughly $19 \%$ of farmers (17\% of acres) reported using continuous no-till (CNT) over a 4 -year period while $28 \%$ of farmers $(26 \%$ of acres) reported alternating no-till (ANT) and 53\% of farmers (57\% of acres) report continuous tillage (CT) (corn was grown in the survey year but was not necessarily grown in all four years). In the soybean survey, roughly $25 \%$ of farmers (23\% of acres) reported CNT over a 4 -year period while $30 \%$ of farmers ( $31 \%$ of acres) reported ANT and $43 \%$ of farmers ( $46 \%$ of acres) reported CT. Although both surveys show that roughly $50 \%$ of producers used no-till during the previous 4 years, less than half of those farmers reported CNT. The rate of no-till use varies regionally as shown in Figures 1 and 2.

In this study, we use data on tillage history as well as current tillage practices to distinguish farms that use no-till continuously from those that alternate notill with other tillage practices. Revealed preference data are used in an ordered logit regression analysis to determine the effect of land characteristics, climate, farm characteristics, and producer demographics on producer choice among tillage regimes. The main contribution of this research is our focus on field-level adoption of no-till over time. In contrast to earlier studies, our data structure and modeling framework allow us to examine the marginal effects of tillage attributes on prolonged no-till use. 


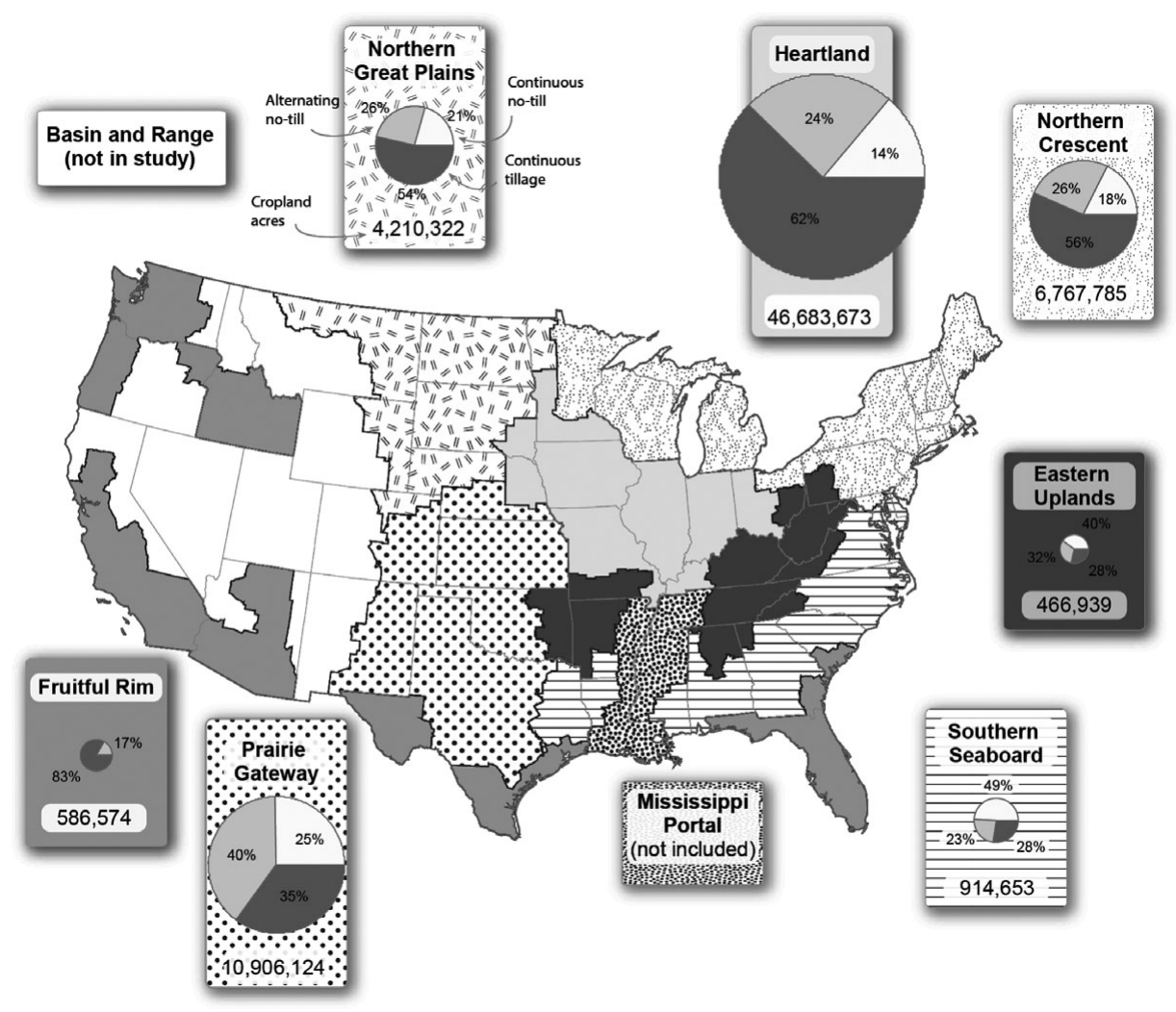

Figure 1. Tillage Adoption for Corn Acres by U.S. Department of Agriculture, Economic Research Service Farm Resource Regions

\section{Literature Review}

The large majority of previous studies of no-till adoption focused on the use of no-till within a single year (see Bergtold and Molnar, 2010; Kurkalova, Kling, and Zhao, 2006; Lambert et al., 2007; Mezzatesta, Newburn, and Woodward, 2013; Pautsch et al., 2001; Soule, 2001; Soule, Tegene, and Wiebe, 2000; Wade, Kurkalova, and Secchi, 2016; Yang, Sheng, and Voroney, 2005). As noted by Prokopy et al. (2008), very few studies have focused on sustained adoption of conservation practices (not just tillage practices) over time. Although these studies have provided a great deal of information on the determinants of no-till adoption, they do not provide insight on the extent of continuous adoption or how these determinants may affect producer decisions to sustain adoption over time.

A smaller group of studies used panel data to assess no-till adoption over time. Many of these studies, however, used data that were aggregated to the county or state level. Ding, Schoengold, and Tadesse (2009) estimated the impact 


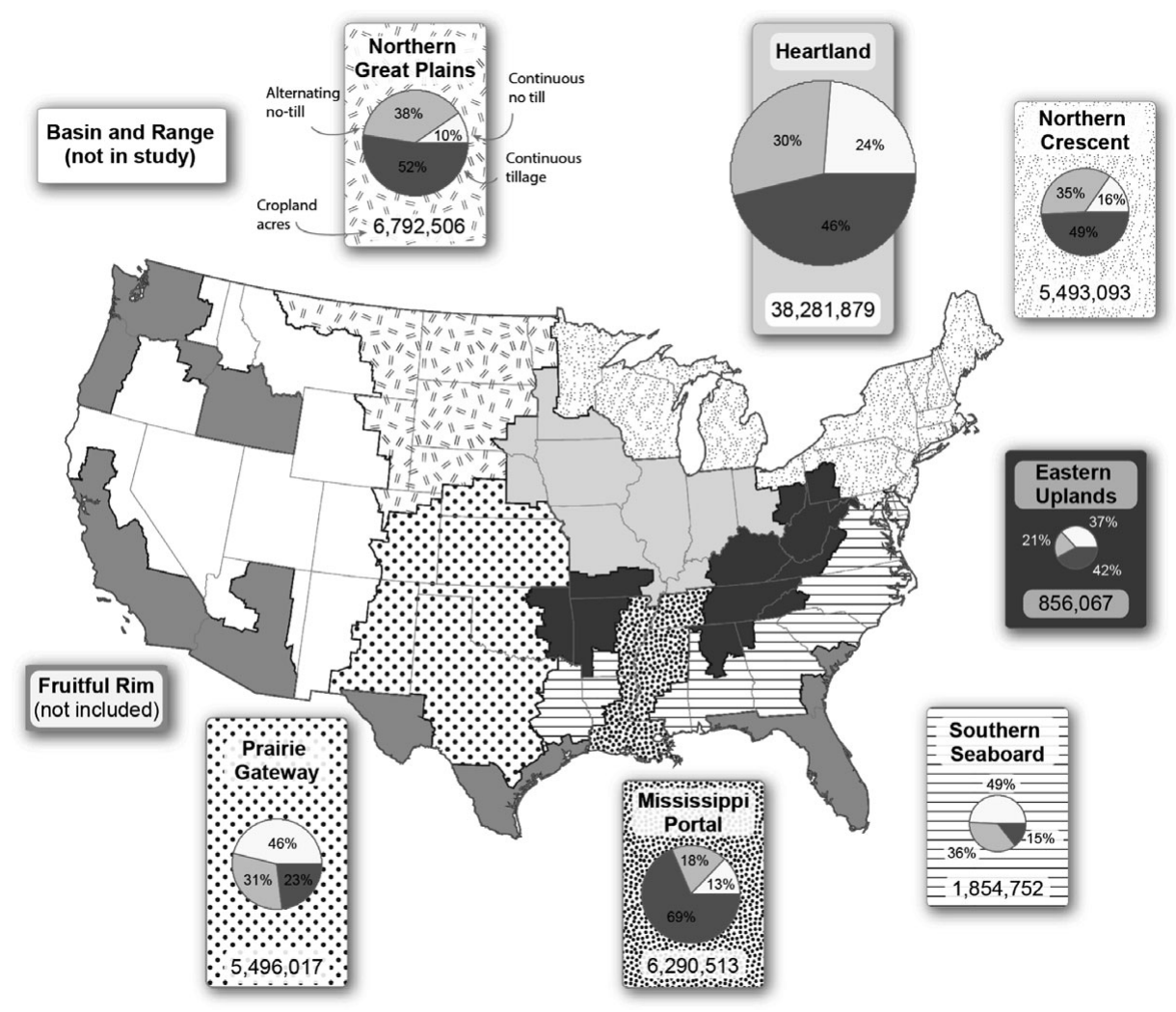

Figure 2. Tillage Adoption for Soybean Acres by U.S. Department of Agriculture, Economic Research Service Farm Resource Regions

of droughts and floods on no-till adoption using county-level data for Iowa, Nebraska, and South Dakota. Schoengold, Ding, and Headlee (2015) used a similar data set to estimate the joint impact of weather and government programs on conservation tillage use. Fernandez-Cornejo et al. (2012) also used countylevel data to examine the effect of herbicide-tolerant soybean adoption on conservation tillage use in major soybean-producing states. In aggregated data, information on sustained adoption for individual fields is lost.

To our knowledge, only one study addresses no-till decisions at the field or farm level, over time, using data on revealed preferences. Recently, Perry, Moschini, and Hennessy (2016) used farm-level panel data to examine complementarity between conservation tillage and herbicide-tolerant crops but did not address the question of continuous adoption.

Agricultural economists have learned that to fully analyze environmental issues they need to understand and incorporate biophysical characteristics (Lichtenberg et al., 2010). In a national study of the effect of land tenure 
on conservation tillage adoption, Soule, Tegene, and Wiebe (2000) found that highly erodible land (HEL) designation had a positive and significant effect on conservation tillage adoption, and inherently wet soil had a negative and significant effect. Schoengold, Ding, and Headlee (2015) estimated the effect of climate and soil properties on no-till adoption in Iowa, Nebraska, and South Dakota and also found that HEL designation had a positive effect on adoption. In estimating the cost of carbon sequestration in Iowa soils, Pautsch et al. (2001) found land slope (a field characteristic that is highly correlated with HEL) to be positively correlated with conservation tillage adoption. Wade, Kurkalova, and Secchi (2016) and Kurkalova, Kling, and Zhao (2006) both estimated the cost of conservation tillage adoption in Iowa and found that subsidies required for farmers to use conservation tillage were lower on HEL than on non-HEL. Many studies use proxies for soil productivity: Yang, Shen, and Voroney (2005) used soil capability class (and aggregate yield data) to interpolate missing fieldlevel yield data in the Fairchild Creek watershed in Ontario, Canada; Secchi et al. (2009) used Iowa's corn suitability rating to estimate field-level yields; and Kurkalova, Kling, and Zhao (2006) used the corn suitability rating to estimate net returns to conventional tillage.

No-till generally is less profitable on cold wet soil (Soule, Tegene, and Wiebe, 2000); therefore, climate regressors are often used in no-till analysis. For example, in studies of conservation tillage adoption in the Upper Mississippi River basin and the Canadian prairies, Wu et al. (2004) and Davey and Furtan (2008), respectively, found negative and significant effects for precipitation and positive and significant effects for temperature, whereas others like Pautsch et al. (2001) examined conservation tillage adoption in Iowa and found the opposite effects for both variables. Wu et al. (2004) also found variation in precipitation to be positively correlated with conservation tillage adoption, whereas Pautsch et al. (2001) had the opposite findings. Kurkalova, Kling, and Zhao (2006) and Wade, Kurkalova, and Secchi (2016) found that temperature had positive and significant effects on conservation tillage adoption. Precipitation is widely used in the literature but is often found to have an insignificant effect on conservation tillage adoption.

Many studies attribute conservation tillage use to farm household and farm characteristics. In a national study of the farm households that adopt best management practices, Lambert et al. (2007) found farm size and education to be positively correlated with adoption of a series of management practices including conservation tillage. Soule, Tegene, and Wiebe (2000) also found positive and significant effects for farm size and college-educated operators and a negative and significant effect for operator's age for conservation tillage adoption. Soule (2001) examined the effect of education on conservation tillage adoption and also found a positive effect. Baumgart-Getz, Prokopy, and Floress (2012) conducted a meta-analysis assessing the attributes affecting best management practices (including no-till) and also found that age had a negative effect whereas 
farm size had a positive effect on adoption. Davey and Furtan (2008) found a similar effect for operator age on conservation tillage. Land tenure was also examined widely in the literature: Baumgart-Getz, Prokopy, and Floress (2012) include several studies that incorporate conservation tillage and land tenure, and Soule (2001) and Davey and Furtan (2008) each found that renters were less likely to adopt conservation tillage. Studies that use ARMS data in conservation analysis also often include the Economic Research Service's (ERS) farm typology. Farm typology describes farms in terms of size, sales, and operator lifestyle, all of which can influence a farmer's adoption decision. Soule (2001) examined conservation tillage adoption by farm typology and found that high-sales farms are more likely to adopt conservation tillage.

Tillage is typically used for weed control (Triplett and Dick, 2008). Operators may choose to alternate between tillage and no-till if cropland becomes resistant to weeds making periodic tilling necessary on some fields (Wilman, 2011). Use of no-till in conjunction with other best management practices, for example, rotating crops or cover crop use, can also help manage weeds. Farmers' tillage choice could also be a function of the crop grown. Many farmers think notill is less compatible with corn than other crops and associate using it with a yield penalty on corn but have no such perception for soybean or wheat (crops typically included in corn rotations) (Reimer, Weinkauf, and Prokopy, 2012). Such perceptions are not unreasonable because no-till yields vary depending on crop rotation, region, climate, and soil type (Ogle, Swan, and Paustian, 2012).

This study is the first to use data on tillage history and current tillage practices to distinguish farms that use no-till continuously from those that alternate notill with other tillage practices. Revealed preference data are used in an ordered logit regression analysis to determine the effect of land characteristics, climate, farm characteristics, and producer demographics on producer choice among tillage regimes. Our primary objective is to develop a richer understanding of producer no-till use decisions. Although the model cannot be used to estimate the difference in profit across the three tillage regimes, it adds to the literature by providing insight into the characteristics and conditions that are conducive to each tillage regime.

\section{The Model and Estimation Procedure}

Farmer $i$ is assumed to make tillage choices that maximize utility. We express utility as an unobserved difference between the utility for no-till and other tillage practices; that is,

$$
y_{i s}^{*}=U_{i s}^{n t}-U_{i s}^{t} \text { for } s=0, \ldots, S .
$$

Here, $s$ is the period in which the tillage choice is observed $(s=0$ indicates the initial period); $y_{i s}^{*}$ is the unobserved net utility of choosing no-till over tillage; $U$ is a farmer's utility; $n t$ indicates no-till use; $t$ indicates tillage use; and $i=1, \ldots, n$ 
indexes individual farmers. Equation (1) can be written as

$$
y_{i s}^{*}=\boldsymbol{\beta}^{\prime} \boldsymbol{X}_{i}+\varepsilon_{i},
$$

where the product $\boldsymbol{\beta}^{\prime} \boldsymbol{X}_{i}$ represents the portion of net utility observed by researchers; $\boldsymbol{X}_{i}$ represents a vector of coregressors thought to affect sustained notill adoption such as soil, farm, climate, regional, and operator characteristics; $\boldsymbol{\beta}$ represents a vector of unknown parameters; and $\varepsilon_{i}$ is the random variable representing the producers' unobserved preference for no-till. However, we observe only the tillage decision in period $s$ :

$$
y_{i s}=1 \text { when } y_{i s}^{*}>0 ; y_{i s}=0 \text { otherwise. }
$$

This implies that the farmer will choose either to till or to use no-till in period $s$. In a multiyear setting, we argue that there is unobserved random variation in profitability of fields and this variation affects whether farmers use the same tillage practice each year or alternate practices. Random shocks may affect yields negatively (and include drought in the previous year, excessive precipitation in the previous year [there may be combine ruts], heavy residue from the previous crop, emergence of herbicide-resistant weeds, machine failures that delay planting, etc.), or shocks could be positive and result from particularly favorable weather, like warm springs and adequate and well-timed precipitation. Over time, these positive and negative shocks likely balance to zero, and experienced farmers can closely predict yields and choose tillage sequences.

For farmers who till continuously, we theorize that the underlying overall relative profitability of no-till must be below a no-till threshold value, $\tau_{1}$, to ensure that it is always more profitable than no-till:

$$
\boldsymbol{\beta}^{\prime} \boldsymbol{X}_{i}+\varepsilon_{i}<\tau_{1}<0 .
$$

Likewise, farmers who use no-till every year must exceed a no-till threshold value, $\tau_{2}$, to ensure that no-till is at least as profitable as tillage:

$$
0<\tau_{2} \leq \boldsymbol{\beta}^{\prime} \boldsymbol{X}_{i}+\varepsilon_{i}
$$

Farmers who alternate practices will fall between the thresholds:

$$
\tau_{1} \leq \boldsymbol{\beta}^{\prime} \boldsymbol{X}_{i}+\varepsilon_{i}<\tau_{2}
$$

We denote farmer $i$ 's multiyear tillage choice as $T_{i}=j$, where $j=1,2,3$ corresponds to CT, ANT, and CNT, respectively, and assume that the farmer's utility (or overall measure of no-till preference), $y_{i}^{*}$, is a random function,

$$
y_{i}^{*}=\boldsymbol{\beta}^{\prime} \boldsymbol{X}_{i}+\varepsilon_{i}
$$

where $y_{i}^{*}$ is the random utility over $S$ periods.

This discrete and ordered dependent variable $\left(T_{i}\right)$ and random utility model lend themselves to an ordered regression model. If the random portion of utility 
follows a logistic distribution, model parameters can be estimated using an ordered logit model. We define

$$
T_{i}=j \text { if } \tau_{j-1}<y_{i}^{*} \leq \tau_{j} \text {, for } \mathrm{j}=1,2,3 \text {, }
$$

where $\tau$ is a vector of unknown thresholds to be estimated by the model, $\tau_{0}=$ $-\infty$, and $\tau_{3}=\infty$. Then the probability that a farmer's utility falls within category $j$ is

$$
\begin{aligned}
\operatorname{Pr}\left[T_{i}=j\right] & =\operatorname{Pr}\left[\tau_{j-1}<y_{i}^{*} \leq \tau_{j}\right] \\
& =\operatorname{Pr}\left[\tau_{j-1}<\boldsymbol{\beta}^{\prime} \boldsymbol{X}_{i}+\varepsilon_{i} \leq \tau_{j}\right] \\
& =\operatorname{Pr}\left[\tau_{j-1}-\boldsymbol{\beta}^{\prime} \boldsymbol{X}_{i}<\varepsilon_{i} \leq \tau_{j}-\boldsymbol{\beta}^{\prime} \boldsymbol{X}_{i}\right] \\
& =\Lambda\left(\tau_{j}-\boldsymbol{\beta}^{\prime} \boldsymbol{X}_{i}\right)-\Lambda\left(\tau_{j-1}-\boldsymbol{\beta}^{\prime} \boldsymbol{X}_{i}\right)
\end{aligned}
$$

where $\Lambda(\cdot)$ is the cumulative distribution function of the logistic distribution (Cameron and Trivedi, 2005). The ordered logit model was used to evaluate the factors that influence sustained no-till adoption. Parameters $\boldsymbol{\tau}$ and $\boldsymbol{\beta}$ are estimated using the maximum likelihood procedure with weighted standard errors.

For this initial analysis of CNT, we estimate a reduced form model. There is evidence suggesting that tillage decisions are made in conjunction with crop choice; for example, some farmers use no-till in soybeans (no-till is used on more than $45 \%$ of soybean acres) but till when producing corn (no-till is used on less than $25 \%$ of corn acres) (Horowitz, Ebel, and Udea, 2010). So the estimated effects of soil, topography, climate, and other factors may affect no-till adoption directly or indirectly through crop choice. Of course, the availability of no-till may also affect the crop. For example, no-till may significantly reduce soil erosion when growing low-residue crops (such as soybeans) on highly erodible cropland. Nonetheless, we focus on the effects of soils, climate, and farm characteristics.

\section{Data Description and Variable Construction}

Data on tillage, field, farm, and farmer characteristics are from the ARMS. The Production Practices and Costs Report (PPCR) is a field-level, commodityspecific survey of production practices. Each survey covers a subset of states accounting for $90 \%-95 \%$ of the production for the surveyed crop. The Costs and Returns Report (CRR) is a farm-level, follow-on survey that provides data on farm and operator characteristics. All data are weighted to ensure that acres sum to state totals. The 2010 corn and 2012 soybean surveys provide usable data on 1,620 and 1,860 fields, respectively (USDA-ERS, 2017).

The dependent variable has three categories identifying no-till intensity over a 4-year period: CT (0 years of no-till), ANT (1-3 years of no-till), and CNT. For fields in ANT, $28 \%, 35 \%$, and $37 \%$ used no-till once, twice, and three times, respectively. No-till in the survey year is indicated by an absence of tillage operations in the spring (as listed by the respondent) and the previous fall as recalled by the respondent. For prior years, we use the same definition of notill, although no-till during both the spring and the previous fall are based 
on producer recall. We believe this definition (Uri, 2000) is aligned with how farmers interpret no-till adoption (i.e., they are not tilling) and therefore is more consistent with the tillage history data, which are based on the respondent's recollection of the previous 3 years of tillage practices. Fallow fields $(1.6 \%$ of acres) and fields in perennial crops $(3.4 \%)$ are excluded from the analysis because farmers do not have to make tillage decisions on these fields. The dependent variable is a quantitative measure of farmers' preferences/attitudes toward CNT making the ordered logit regression model appropriate.

\subsection{Soil Characteristics}

HEL and well-drained land are more likely to be in no-till (see, e.g., Prokopy et al., 2008; Soane et al., 2012; Soule, Tegene, and Wiebe, 2000). On HEL, producers who participate in farm programs must apply approved conservation systems or risk losing eligibility (Secchi et al., 2009). A field's erodibility status is a binary variable reported by the farm operator. It is expected to positively affect no-till adoption. Soil drainage is also important because leaving residue on poorly drained soil slows soil drying and may delay planting. No-till has potential to increase yields and store soil organic carbon when used on moderateto well-drained soils (Kumar et al., 2012; Triplett and Dick, 2008). Conversely, decreased yields may be noticed when used on poorly drained soils (Ogle, Swam, and Paustian, 2012). This binary variable identifies moderate- to welldrained soils and is derived from the Soil Survey Geographic Database majority drainage class code within a $300 \mathrm{~m}$ neighborhood (USDA-NRCS, 2014). The average National Commodity Crop Productivity Index (NCCPI) is used to measure soil productivity (Dobos, Sinclair, and Robotham, 2012). Prokopy et al. (2008) suggest that increased soil quality negatively affects conservation practice adoption.

\subsection{Farm Characteristics}

Irrigation, farm size, and farm typology are thought to affect tillage adoption. Approximately $12 \%$ of corn and $10 \%$ of soybean acres are irrigated with $70 \%$ of irrigated acres in the Heartland and Prairie Gateway. Residue left on irrigated fields may impede the movement of irrigation water. Irrigated fields tend to have cooler soil and residue may further slow the warming of the soil (Ogle, Swam, and Paustian, 2012). Also, because no-till is often used as a soil moisture conservation technique, it may be treated as a substitute to irrigation and not used simultaneously. A binary indicator of irrigation is available from the PPCR.

Because larger farms can spread fixed costs (such as investment in no-till equipment) over more acres, no-till may be more attractive to these farms (Lambert et al., 2007; Robertson et al., 2014; Soule, Tegene, and Weibe, 2000). The log of total cropland acreage and the ERS farm typology are used to capture this effect. The farm typology is a seven-category classification based on gross sales, the operator's primary occupation, and family farm status (Hoppe and 
MacDonald, 2013). We use the typology "collapsed" into three groups: ruralresidential, intermediate, or commercial farms. Because farm sales are closely related to cropland acreage, we expect that commercial and intermediate farms are more likely to use CNT.

\subsection{Regional Indicators and Climate Characteristics}

Regional dummies for each USDA farm resource region are included (USDA-ERS, 2000). Of the 3,480 observations, the Southern Seaboard and Eastern Uplands have $1.5 \%$ and $0.6 \%$ of sampled corn acres and $3.4 \%$ and $1.4 \%$ of sampled soybean acres, respectively. ${ }^{1}$ These regions are combined to form the "Southeast" region because they have similar crop mixes and climate. The Fruitful Rim includes only $1.1 \%$ of acres represented by the corn sample. To preserve these observations, those in Texas were combined with the Prairie Gateway (18 observations or $1.1 \%$ of acres), and those in Georgia were combined with the Southeast region (3 observations or $0.01 \%$ of acres).

Climate regressors are constructed from PRISM (parameter-elevation relationships on independent slopes model) monthly average county-level data for the corn and soybeans growing seasons: April through October for corn and May through October for soybeans (USDA, National Agricultural Statistical Service, 2010). We include 30-year average temperature, average precipitation, variability in monthly temperature, and variability in monthly precipitation. This captures the within-season and cross-season variability in climate. We also include the square of average temperature, the square of average precipitation, and the interaction between average temperature and precipitation to capture the nonlinear relationship between tillage choice and climate (Auffhammer et al., 2013) and the combined effect of temperature and rainfall. High average temperatures are expected to be positively correlated with no-till adoption whereas high levels of average precipitation may negatively affect adoption. This is consistent with no-till operating poorly on cold wet soil (Ogle, Swam, and Paustian, 2012; Soule, Tegene, and Wiebe, 2000). Variability in temperature and precipitation, captured by their respective variability variables, may correlate with inconsistent yields making traditional tillage systems more attractive and hence less likely to adopt no-till.

\subsection{Operator Characteristics}

Proxies for farmer experience are used widely with mixed results (see Knowler and Bradshaw, 2007; Prokopy et al., 2008; Wu and Babcock, 1998). Here, age proxies for farmer experience. Studies have also postulated that younger farmers are more likely to adopt conservation practices because their longer farming horizons afford them time to recapture the cost of new equipment and training

1 Note that these proportions may differ from those in Figures 1 and 2 because acres in the figure are from the PPCR and acres in the analysis result from merging the PPCR with the CRR. The difference in the proportions is a result of observations that are lost after the surveys were merged. 
(Baumgart-Getz, Prokopy, and Floress, 2012; Lambert et al., 2007). Wu and Babcock (1998) theorize that this negative correlation with conservation tillage adoption is because of long farming tradition and cultural practices.

Like Lambert et al. (2007) we hypothesize that full owners, who have a longterm interest in soil health and profitability, are more likely to adopt practices that help improve long-term soil health, including CNT. We note, however, that tenure is used frequently to explain conservation practice adoption with varying results (Prokopy et al., 2008).

College education is also often associated with conservation practices adoption (e.g., D'Emden, Llewellyn, and Burton, 2008; Gould, Saupe, and Klemme, 1989; Prokopy et al., 2008; Rahm and Huffman, 1984; Soule, Tegene, and Weibe, 2000; Wu and Babcock, 1998).

Though not examined directly in this analysis, cropping patterns may play an important role in the tillage decision. Some authors find that farmers alternate tillage with specific crops (Robertson et al., 2014). During the 3-year cropping history, $5 \%$ of sampled corn acres and $7 \%$ of sampled soybean acres were planted in crops other than corn or soybeans (with farmers in the soybean sample planting soybeans on $86 \%$ of cropland and farmers in the corn sample planting soybeans on $69 \%$ of cropland). Because cropping history is endogenous, we opt to estimate a reduced-form model with only exogenous variables that change slowly over time (e.g., farm size, age, and education).

The final samples have 1,155 observations for corn and 1,324 for soybeans representing 85 million acres. The average field size is 52 acres. Table 1 summarizes the descriptions and provides descriptive statistics of the common observations. All statistics are weighted by state crop acres.

\section{Results}

Table A1, available in the online supplementary appendix, provides the ordered logit parameter estimates for our three categories of no-till adoption by crop. Positive coefficient estimates indicate that an increase in the value of the variable will increase the probability of CNT, whereas negative estimates indicate an increase in the probability of CT. With Wald chi-square statistic of 121.94 for the corn sample and 258.99 for soybeans $(P$ values $<0.001)$, we reject the hypothesis that the specification with only cut points, $\tau$, is not significantly different from the present models. Though the climate variables are correlated, for the corn sample, the difference in the Akaike information criterion (AIC) for the model without variability in climate regressors $(1,364)$ and the model with climate variability $(1,358)$ provides insufficient evidence to omit these variables from the analysis. This is also the case for the soybean sample where the AIC for the model without variability in climate regressors is 1,080 and the AIC for the model with climate variability is 1,069 . Designating the largest of the three predicted probabilities as the predicted outcome, there are $56 \%$ correct 
Table 1. Descriptions of Variables and Summary Statistics

\begin{tabular}{|c|c|c|c|c|c|}
\hline \multirow[b]{2}{*}{ Variable } & \multirow[b]{2}{*}{ Description } & \multicolumn{2}{|c|}{ Corn } & \multicolumn{2}{|c|}{ Soybeans } \\
\hline & & Mean & $\begin{array}{l}\text { Standard } \\
\text { Deviation }\end{array}$ & Mean & $\begin{array}{l}\text { Standard } \\
\text { Deviation }\end{array}$ \\
\hline NCCPI & $\begin{array}{l}\text { Mean of the National Commodity } \\
\text { Crop Productivity Index within } \\
300 \mathrm{~m}\end{array}$ & 57.4 & 20.4 & 58.6 & 18.8 \\
\hline Highly Erodible Land & $\begin{array}{l}\text { 1, Land is classified as highly } \\
\text { erodible }\end{array}$ & 0.109 & 0.311 & 0.143 & 0.351 \\
\hline Well-Drained Soil & $\begin{array}{l}\text { 1, Soil is excessively to moderately } \\
\text { well drained }\end{array}$ & 0.627 & 0.484 & 0.578 & 0.494 \\
\hline Irrigated Field & $\begin{array}{l}\text { 1, Any portion of the field is } \\
\text { irrigated }\end{array}$ & 0.061 & 0.240 & 0.079 & 0.270 \\
\hline Log of Cropland & Natural log of the total cropland & 6.51 & 1.11 & 6.53 & 1.20 \\
\hline Residence Farm & $\begin{array}{l}\text { 1, Farm is a residential or lifestyle } \\
\text { farm }\end{array}$ & 0.102 & 0.302 & 0.120 & 0.325 \\
\hline Intermediate Farm & 1, Farm is an intermediate farm & 0.183 & 0.387 & 0.226 & 0.418 \\
\hline Commercial Farm & 1 , Farm is a commercial farm & 0.715 & 0.452 & 0.654 & 0.476 \\
\hline Heartland & 1, Field is in the Heartland & 0.608 & 0.488 & 0.581 & 0.494 \\
\hline Northern Crescent & 1 , Field is in the Northern Crescent & 0.216 & 0.412 & 0.151 & 0.358 \\
\hline Northern Great Plains & $\begin{array}{l}\text { 1, Field is in the Northern Great } \\
\text { Plains }\end{array}$ & 0.035 & 0.184 & 0.043 & 0.204 \\
\hline Prairie Gateway & 1, Field is in the Prairie Gateway & 0.099 & 0.299 & 0.066 & 0.249 \\
\hline Southeast & 1, Field is in the Southeast & 0.042 & 0.200 & 0.050 & 0.218 \\
\hline Mississippi Portal & 1, Field is in the Mississippi Portal & & & 0.108 & 0.311 \\
\hline Average Temp & $\begin{array}{l}\text { Average of monthly temperature } \\
\text { during the crop growing season } \\
\left({ }^{\circ} \mathrm{C}\right)\end{array}$ & 17.41 & 2.08 & 19.33 & 2.19 \\
\hline Temp Variability & $\begin{array}{l}\text { Variance of monthly temperature } \\
\text { during the crop growing season }\end{array}$ & 26.71 & 4.06 & 18.98 & 3.19 \\
\hline Average Precip & $\begin{array}{l}\text { Average of monthly precipitation } \\
\text { during the crop growing season } \\
(\mathrm{mm})\end{array}$ & 91.7 & 11.8 & 94.5 & 10.1 \\
\hline Precip Variability & $\begin{array}{l}\text { Variance of monthly precipitation } \\
\text { during the crop growing season }\end{array}$ & 2597 & 835 & 2812 & 882 \\
\hline Log of Age & $\begin{array}{l}\text { Natural log of operator's age (log } \\
\text { years) }\end{array}$ & 3.99 & 0.21 & 4.02 & 0.21 \\
\hline Tenure & 1, Operator is a full owner & 0.522 & 0.500 & 0.470 & 0.499 \\
\hline College Graduate & $\begin{array}{l}\text { 1, Operator graduated from } \\
\text { college }\end{array}$ & 0.210 & 0.407 & 0.237 & 0.425 \\
\hline
\end{tabular}

predictions for corn and $53 \%$ for soybeans. The rate of correct predictions does not seem low considering we observe several levels of no-till intensity (Wang, Young, and Camara, 2000). Estimates for the ordered probit model using the identical specification are virtually identical to the ordered logit model in terms of number of correct predictions, predicted probabilities, and log likelihood.

On average, the estimated probabilities are equal to the observed shares of each tillage category in both models (Table 2). Regionally, the largest differences 
Table 2. Proportion of Fields and Predicted Probabilities in Each Tillage Category by Region

\begin{tabular}{|c|c|c|c|c|c|c|c|c|c|}
\hline \multirow[b]{3}{*}{ Corn } & \multicolumn{3}{|c|}{ Continuous Tillage } & \multicolumn{3}{|c|}{ Alternating No-Till } & \multicolumn{3}{|c|}{ Continuous No-Till } \\
\hline & \multirow{2}{*}{$\begin{array}{l}\text { Proportion } \\
0.5374\end{array}$} & \multicolumn{2}{|c|}{ Probability } & \multirow{2}{*}{$\begin{array}{l}\text { Proportion } \\
0.2937\end{array}$} & \multicolumn{2}{|c|}{ Probability } & \multirow{2}{*}{$\begin{array}{l}\text { Proportion } \\
0.1689\end{array}$} & \multicolumn{2}{|c|}{ Probability } \\
\hline & & 0.5387 & $(0.0194)$ & & 0.2934 & $(0.0195)$ & & 0.1679 & $(0.0173)$ \\
\hline Heartland & 0.5636 & 0.5631 & $(0.0231)$ & 0.2899 & 0.2887 & $(0.0209)$ & 0.1465 & 0.1482 & $(0.0162)$ \\
\hline Northern Crescent & 0.5333 & 0.5409 & $(0.0553)$ & 0.2867 & 0.2917 & $(0.0264)$ & 0.1800 & 0.1674 & $(0.0382)$ \\
\hline Northern Great Plains & 0.5563 & 0.5677 & $(0.0634)$ & 0.3249 & 0.2938 & $(0.0370)$ & 0.1188 & 0.1385 & $(0.0336)$ \\
\hline Prairie Gateway & 0.4280 & 0.4441 & $(0.0439)$ & 0.3406 & 0.3101 & $(0.0246)$ & 0.2314 & 0.2457 & $(0.0394)$ \\
\hline Southeast & 0.4221 & 0.3721 & $(0.0823)$ & 0.2468 & 0.3310 & $(0.0276)$ & 0.3311 & 0.2969 & $(0.0732)$ \\
\hline Soybeans & 0.4521 & 0.4537 & $(0.0153)$ & 0.2932 & 0.2933 & $(0.0156)$ & 0.2547 & 0.2529 & $(0.0140)$ \\
\hline Heartland & 0.4393 & 0.4396 & $(0.0195)$ & 0.3116 & 0.3115 & $(0.0173)$ & 0.2491 & 0.2489 & $(0.0165)$ \\
\hline Northern Crescent & 0.5387 & 0.5404 & $(0.0460)$ & 0.2896 & 0.2877 & $(0.0223)$ & 0.1717 & 0.1719 & $(0.0297)$ \\
\hline Northern Great Plains & 0.5410 & 0.5578 & $(0.0463)$ & 0.342 & 0.2765 & $(0.0245)$ & 0.1170 & 0.1657 & $(0.0289)$ \\
\hline Prairie Gateway & 0.1794 & 0.2078 & $(0.0360)$ & 0.3283 & 0.3080 & $(0.0226)$ & 0.4923 & 0.4842 & $(0.0505)$ \\
\hline Southeast & 0.1607 & 0.1974 & $(0.0506)$ & 0.3743 & 0.3131 & $(0.0333)$ & 0.4650 & 0.4896 & $(0.0792)$ \\
\hline Mississippi Portal & 0.6667 & 0.6367 & $(0.0420)$ & 0.1201 & 0.1923 & $(0.0170)$ & 0.2133 & 0.1709 & $(0.0338)$ \\
\hline
\end{tabular}

Note: Standard errors in parentheses. 
between predictions and shares are for ANT in regions that include a relatively small share of observations: $8 \%$ for corn in the Southeast (4\% of observations) and $7 \%$ for soybeans in the Mississippi Portal (10\% of observations).

For both the corn and soybean survey, the adoption rate for CNT is substantially less than that of ANT or CT. In the corn survey, 54\% of respondents used CT over the 4-year period. Just under $30 \%$ alternated tillage with no-till while $17 \%$ used no-till continuously. In the soybean survey, $45 \%$ used CT while just under $30 \%$ indicated ANT and 25\% used CNT. For the regions heavily represented in the sample (Heartland, Northern Crescent, Northern Great Plains, and Prairie Gateway), respondents in the Prairie Gateway report a much higher rate of CNT (23\% in the corn survey and $50 \%$ in the soybean survey).

\subsection{Marginal Effects for Corn Producers}

\subsubsection{Soil Characteristics}

A marginal increase in NCCPI is estimated to increase the probability of adopting CT by $0.3 \%$, decrease the probability of ANT by $0.12 \%$, and decrease the probability of CNT adoption by $0.18 \%$ (Table 3 ). NCCPI is defined over a range of $0-100$, but most land in our sample has values between 20 and 80 . A simple approximation using the average marginal effects indicates that the probability of CT would be roughly $18 \%$ higher at the upper end of the range (NCCPI = $80)$ than at the lower end (NCCPI $=20$ ) while the probabilities of ANT and CNT would be roughly $7.2 \%$ and $10.8 \%$ lower for the same range, respectively. The effects of NCCPI on ANT and CNT are not statistically different, so it is not clear that an increase in land productivity increases the probability of CNT more rapidly than the probability of ANT.

The role of NCCPI may be explained by the perceived risk of using no-till or perceived no-till yield penalty in corn (Ogle, Swan, and Paustian, 2012; Reimer, Weinkauf, and Prokopy, 2012). Although many crops other than corn appear in the crop history, $95 \%$ of respondents planted corn in the same field at least once in the previous 3 years and $18 \%$ planted corn in each of the previous 3 years. $^{2}$ If higher corn yields result in a larger yield penalty for corn in no-till, the absolute revenue loss because of no-till adoption could be higher where NCCPI is higher.

The highly erodible designation is, perhaps, the single most important determinant of CNT use. This is similar to other studies that find a positive relationship between erodible land and conservation practice adoption (see Ding, Schoengold, and Tadesse, 2009). HEL designation increases the probability of CNT adoption by $12 \%$, on average, and increases the probability of ANT by

2 Issues related to residue management, crop diseases such as gray leaf spot, pest management, and weed management (Bullock, 1992; Soane et al., 2012) are possible reasons why farmers who plant monocultures are less likely to use no-till systems. Increasing demand for corn could make continuous corn attractive on cropland that can sustain profitable corn intensive rotations and make no-till less likely on these fields. 
Table 3. Ordered Logit Average Marginal Effects Estimates for Corn

\begin{tabular}{|c|c|c|c|c|c|c|}
\hline \multirow{2}{*}{$\begin{array}{l}\text { Variable } \\
\text { NCCPI }\end{array}$} & \multicolumn{2}{|c|}{ Continuous Tillage } & \multicolumn{2}{|c|}{ Alternating No-Till } & \multicolumn{2}{|c|}{ Continuous No-Till } \\
\hline & 0.0030 & $(0.0012)^{* *}$ & -0.0012 & $(0.0005)^{* *}$ & -0.0018 & $(0.0007)$ \\
\hline Highly Erodible Land & -0.1735 & $(0.0598)^{* * *}$ & 0.0524 & $(0.0142)^{* * *}$ & 0.1211 & $(0.0491)^{* *}$ \\
\hline Irrigated Field & 0.0937 & $(0.0656)$ & -0.0428 & $(0.0333)$ & -0.0509 & $(0.0328)$ \\
\hline Log of Cropland & -0.0632 & $(0.0227)^{* * *}$ & 0.0257 & $(0.0092)^{* * *}$ & 0.0375 & $(0.0142)^{* * *}$ \\
\hline Intermediate Farm & -0.0926 & $(0.0615)$ & 0.0306 & $(0.0232)$ & 0.0621 & $(0.0401)$ \\
\hline Commercial Farm & 0.0275 & $(0.0696)$ & -0.0116 & $(0.0286)$ & -0.0159 & $(0.0411)$ \\
\hline Northern Crescent & -0.1311 & $(0.0711)^{*}$ & 0.0443 & $(0.0173)^{* *}$ & 0.0867 & $(0.0549)$ \\
\hline Northern Great Plains & -0.2469 & $(0.089)^{* * *}$ & 0.0463 & $(0.0164)^{* * *}$ & 0.2006 & $(0.1001)^{* *}$ \\
\hline Prairie Gateway & -0.0918 & $(0.0897)$ & 0.0324 & $(0.0267)$ & 0.0594 & $(0.0635)$ \\
\hline Southeast & -0.1106 & $(0.1068)$ & 0.0364 & $(0.0259)$ & 0.0742 & $(0.0816)$ \\
\hline Average Temp & -0.0655 & $(0.0202)^{* * *}$ & 0.0386 & $(0.0100)^{* * *}$ & 0.0269 & $(0.0119)^{* *}$ \\
\hline Temp Variability & 0.0238 & $(0.0109)$ & -0.0097 & $(0.0047)$ & -0.0141 & $(0.0064)^{* *}$ \\
\hline Average Precip & 0.0002 & $(0.0044)$ & -0.0001 & $(0.0018)$ & -0.0001 & $(0.0026)$ \\
\hline Precip Variability & -0.00003 & $(0.0001)$ & 0.00001 & $(0.00002)$ & 0.00002 & $(0.00003)$ \\
\hline Tenure & -0.0273 & $(0.0386)$ & 0.0111 & $(0.0156)$ & 0.0162 & $(0.0231)$ \\
\hline College Graduate & 0.0136 & $(0.0427)$ & -0.0056 & $(0.0177)$ & -0.008 & $(0.025)$ \\
\hline
\end{tabular}

Notes: Marginal effect for factor levels is the discrete change from the base level. Standard errors in parentheses. ${ }^{*} P<0.10,{ }^{* *} P<0.05$, ${ }^{* * *} P<0.01$. 
$5 \%$, on average $(5 \%$ and $1 \%$ level of significance, respectively). Moreover, the CNT estimate is statistically significantly different from ANT, indicating that HEL designation increases the likelihood of CNT relative to ANT.

The effect of HEL designation may be attributable, at least in part, to conservation compliance, which requires that producers apply approved soil conservation plans on highly erodible cropland to maintain eligibility for most federal farm-related payments including commodity payments, crop insurance subsidies, and conservation payments. The actual effect of conservation compliance, however, is difficult to understand without more complete information on the conservation systems approved for use on individual fields. A range of soil conservation practices, including no-till and other forms of conservation tillage, could be used to satisfy conservation compliance requirements. To the extent that no-till is required by soil conservation plans, the higher probability of CNT and ANT could be accounted for by the potential cost of noncompliance and the cost of other options for controlling soil erosion.

Like De La Torre Ugarte, Hellwinckel, and Larson (2004), we find a positive correlation between no-till use and well-drained soils. Well-drained soils are also more likely to be in CNT than soils that tend to drain slowly. For the corn sample, we estimate that the probability of CNT is roughly $8 \%$ higher and the probability of ANT is roughly $7 \%$ higher on moderately well-drained and welldrained soils. These estimates are not statistically significantly different from each other, indicating that soil drainage increases the probability of both CNT and ANT to a similar degree.

Figure 3 illustrates the changes in average predicted probabilities (assuming nonirrigated cropland and holding all other variables at their means) for four types of land: non-HEL and poorly drained, non-HEL and well drained, HEL and poorly drained, and HEL and well drained. The figure shows little variation in the average probability of ANT but far more variability in the probabilities of CNT and CT use. For well-drained cropland (the second and fourth clusters in Figure 3), HEL designation increases the probability of CNT by $18 \%$ (from $24 \%$ to $42 \%$ ). For poorly drained cropland (clusters 1 and 3), HEL designation increases the probability of CNT by $13 \%$ (from $13 \%$ to $26 \%$ ). When conditions are poorly suited for no-till (cluster 1), the average predicted probability of CT is $55 \%$, more than four times larger than CNT and almost twice as large as ANT. On non-HEL, well-drained cropland, which includes $49 \%$ of nonirrigated fields in the corn survey, the average predicted probability of CT is higher than CNT by $13 \%$ and the average probability of ANT is higher than CNT by $15 \%$. That is, tillage during the 4-year period is about three times more likely than CNT. ${ }^{3}$

3 The online supplementary appendix provides graphs that further explore the marginal effects of soil properties, farm size, and climate variables for each region. 


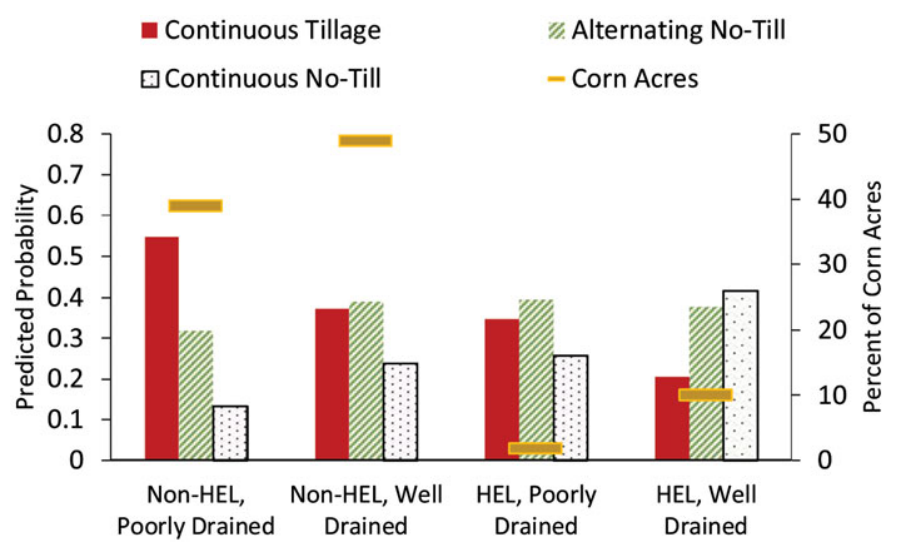

Figure 3. Average Predicted Probabilities by Drainage and Highly Erodible Land (HEL) Classification for Nonirrigated Corn Fields

\subsubsection{Farm Characteristics}

Like Lambert et al. (2007) and Robertson et al. (2014), we find that farm size has a positive and significant effect on conservation practice use. On average, a $1 \%$ increase in cropland acres increases the probability of CNT by $0.04 \%$ and increases the probability of ANT by $0.03 \%$. Both are significantly different from zero at the $1 \%$ level but are not significantly different from each other. These results are consistent with the conclusion that small farmers are not necessarily better land stewards than large farmers (Soule, 2001). Most farms in this study have cropland acreage between 150 acres and 3,000 acres.

\subsubsection{Regional Indicators and Climate Characteristics}

On average, the majority of corn sample respondents are located in areas that have average temperatures between $15^{\circ} \mathrm{C}$ and $20^{\circ} \mathrm{C}$ during the growing season. Using the average marginal effects, the model predicts that a $5^{\circ} \mathrm{C}$ increase in average temperature, ceteris paribus, increases the probabilities of CNT by $13 \%$ and ANT by $19 \%$ and decreases the probability of CT by $33 \%$. These results are consistent with no-till being more attractive in warmer regions (Ding, Schoengold, and Tadesse, 2009).

\subsection{Marginal Effects for Soybean Producers}

\subsubsection{Soil Characteristics}

Unlike corn, NCCPI is not found to have a significant effect on no-till adoption (Table 4). This may be because of the lack of yield penalty associated with no-till soybeans (Yin and Al-Kaisi, 2004). Although there are many crops in the yield 
Table 4. Ordered Logit Average Marginal Effects Estimates for Soybeans

\begin{tabular}{|c|c|c|c|c|c|c|}
\hline \multirow[b]{2}{*}{ NCCPI } & \multicolumn{2}{|c|}{ Continuous Tillage } & \multicolumn{2}{|c|}{ Alternating No-Till } & \multicolumn{2}{|c|}{ Continuous No-Till } \\
\hline & -0.0005 & $(0.0008)$ & 0.0001 & $(0.0002)$ & 0.0004 & $(0.0006)$ \\
\hline Highly Erodible Land & -0.2046 & $(0.0391)^{* * *}$ & 0.009 & $(0.0085)$ & 0.1957 & $(0.0438)^{* * *}$ \\
\hline Well-Drained Soil & -0.1462 & $(0.0311)^{* * *}$ & 0.0327 & $(0.0082)^{* * *}$ & 0.1135 & $(0.0246)^{* * *}$ \\
\hline Irrigated Field & 0.0694 & $(0.0571)$ & -0.0177 & $(0.0172)$ & -0.0517 & $(0.0400)$ \\
\hline Log of Cropland & -0.0611 & $(0.0202)^{* * *}$ & 0.0122 & $(0.0046)^{* * *}$ & 0.0488 & $(0.0162)^{* * *}$ \\
\hline Intermediate Farm & 0.0715 & $(0.0538)$ & -0.0085 & $(0.0061)$ & -0.063 & $(0.0497)$ \\
\hline Northern Crescent & -0.0494 & $(0.0527)$ & 0.0083 & $(0.0069)$ & 0.0411 & $(0.0460)$ \\
\hline Northern Great Plains & -0.2918 & $(0.0487)^{* * *}$ & -0.043 & $(0.0341)$ & 0.3348 & $(0.0811)^{* * *}$ \\
\hline Prairie Gateway & -0.2578 & $(0.0445)^{* * *}$ & -0.0131 & $(0.0172)$ & 0.2709 & $(0.0594)^{* * *}$ \\
\hline Southeast & -0.1149 & $(0.0752)$ & 0.0114 & $(0.0041)^{* * *}$ & 0.1035 & $(0.0763)$ \\
\hline Mississippi Portal & -0.2699 & $(0.0679)^{* * *}$ & -0.0377 & $(0.0433)$ & 0.3076 & $(0.1101)^{* * *}$ \\
\hline Average Temp & -0.0063 & $(0.0188)$ & 0.0156 & $(0.0063)^{* *}$ & -0.0093 & $(0.0135)$ \\
\hline Temp Variability & 0.0405 & $(0.0119)$ & -0.0081 & $(0.0027)^{* * *}$ & -0.0323 & $(0.0095)^{* * *}$ \\
\hline Average Precip & 0.0014 & $(0.0034)$ & -0.0006 & $(0.0007)$ & -0.0008 & $(0.0027)$ \\
\hline Log of Age & -0.0354 & $(0.0683)$ & 0.0071 & $(0.0137)$ & 0.0283 & $(0.0546)$ \\
\hline Tenure & 0.0308 & $(0.0284)$ & -0.0062 & $(0.0058)$ & -0.0246 & $(0.0227)$ \\
\hline College Graduate & 0.0183 & $(0.0352)$ & -0.0038 & $(0.0078)$ & -0.0145 & $(0.0274)$ \\
\hline
\end{tabular}

Notes: Marginal effect for factor levels is the discrete change from the base level. Standard errors in parentheses. ${ }^{*} P<0.10,{ }^{* *} P<0.05$, ${ }^{* * *} P<0.01$. 


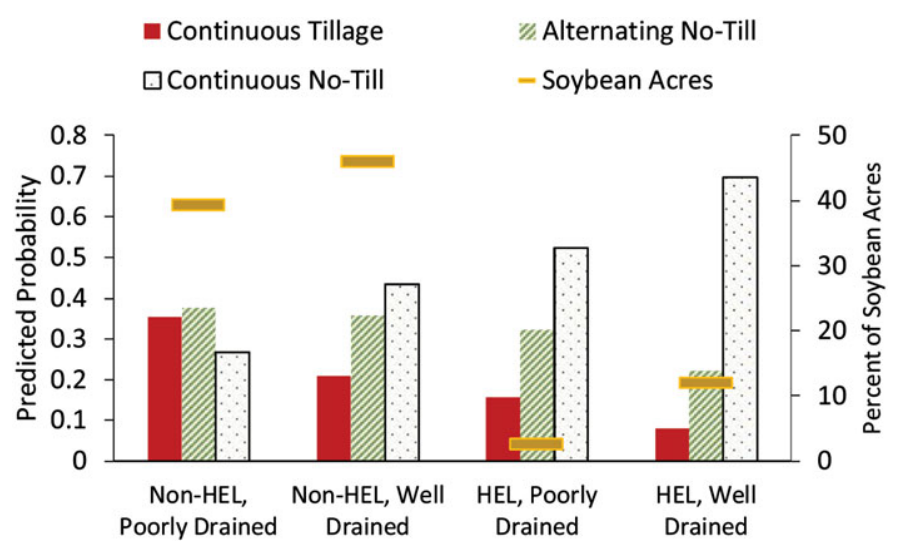

Figure 4. Average Predicted Probabilities by Drainage and Highly Erodible Land (HEL) Classification for Nonirrigated Soybean Fields

histories in the soybean survey, a large proportion of fields were planted with soybeans in previous years: $93 \%$ of soybean acres planted soybeans at least once in the previous 3 years, whereas only $74 \%$ of acres in the corn survey were in soybeans at least once in the previous 3 years. This difference reflects the regions sampled. The soybean sample draws more heavily on southeastern states where soybeans are more likely than corn and warm conditions are more conducive to no-till.

HEL designation increases the probability of CNT by $20 \%$ but does not significantly increase the probability of ANT-a larger effect than estimated for the corn sample. Producers who are subject to conservation compliance or concerned about soil erosion may see no-till, particularly on soybeans, as an important component of their overall soil conservation plan. Well-drained land increases the probability of CNT by $11 \%$ and the probability of ANT by $3 \%-a$ much smaller and statistically different result.

Figure 4 illustrates the changes in average predicted probabilities (assuming nonirrigated cropland and holding all other variables at their means) for four types of land: non-HEL and poorly drained, non-HEL and well drained, HEL and poorly drained, and HEL and well drained. As expected, the predicted probabilities for CNT in the soybean sample are higher for all drainage-HEL combinations than for the corn sample. Only considering well-drained cropland (the second and fourth cluster in Figure 4), we see that on average, HEL designation increases the probability of CNT from $43 \%$ to $70 \%$ and decreases the probability of ANT from $36 \%$ to $22 \%$. Only considering poorly drained cropland (clusters 1 and 3), HEL designation increases the probability of CNT from $27 \%$ to $52 \%$ and increases the probability of ANT from $38 \%$ to $32 \%$. For non-HEL, poorly drained cropland, the average probability of CT $(35 \%)$ exceeds the probability of CNT $(27 \%)$ by $9 \%$ points and is almost equal to the 
average probability of ANT ( $38 \%$ ). Both the corn and soybean models estimate, on average, small changes in ANT and larger shifts in CT as cropland moves from soil that is well suited for no-till to soil that is less suited for no-till (or from left to right in Figure 4).

\subsubsection{Farm Characteristics}

Like corn fields, the results also suggest that larger farms have a higher probability of adopting CNT. On average, a $1 \%$ increase in cropland acres increases the probability of ANT by $0.01 \%$ and increases the probability of CNT by $0.05 \%$ (each at the $1 \%$ significance level). Though the confidence intervals for the two estimates overlap, the estimate for the average marginal effect of the log of cropland for CNT adoption is not included in the range of estimates for ANT. This implies that farm size plays a larger role in sustained adoption on soybean fields than on corn fields, at least for our 4 years of data.

\subsubsection{Regional Indicators and Climate Characteristics}

Average temperature plays a far less significant role in CNT use on soybean fields than on corn fields. Average temperature increases the probability of ANT by $2 \%$ at the $5 \%$ significance level but does not significantly affect the use of CNT or CT. However, variability in average growing season temperatures plays a significant role in sustained adoption. A unit increase in temperature variability decreases the probability of ANT by $0.8 \%$ and decreases the probability of CNT by $3 \%$. These results are significant at the $1 \%$ level and are statistically distinct. The variance of average temperature for most of the cropland in our sample ranges between $15^{\circ} \mathrm{C}$ and $24^{\circ} \mathrm{C}$. Average marginal effects suggest that the probability of CNT would be $29 \%$ lower at the upper range $\left(24^{\circ} \mathrm{C}\right)$ than at the lower range $\left(15^{\circ} \mathrm{C}\right)$, and ANT would be $7 \%$ lower for the same range. This implies that although soybeans are less dependent on warm temperature during the growing season, farmers may choose to regulate soil temperature by tilling if there is uncertainty in monthly temperatures.

\section{Conclusion}

CNT use has the potential to significantly increase carbon sequestration in cropland as well as improve soil health and mitigate sediment and nutrient losses, but fields need more than 5 years of CNT to reach their full potential for building organic matter (Toliver et al., 2012), improving soil structure, and water-holding capacity.

This article is the first to examine attributes affecting the continuous use of no-till. It is a national study using field-level tillage data on farmer choices over a 
4-year period grouped into three ordered levels of no-till use: CT, ANT, and CNT. An ordered logit regression was used to estimate the effect soil, climate, regional, farm, and farmer characteristics have on farmers' use of CNT. The regression results provide a first look at how these characteristics affect the probabilities of alternating and continuous no-till use.

Results regarding HEL designation suggest that conservation compliance requirements may be driving some no-till adoption. For both the corn and soybean samples, the rate of CNT is roughly twice as high on HEL as on non-HEL. Nonetheless, most corn and soybeans are grown on non-HEL, and a majority of no-till acreage is on non-HEL. Soil drainage, climate, and farm size also appear to have a significant effect on no-till use.

Our results could be consistent with more than one adoption scenario. For example, producers who alternate no-till with other tillage practices may have reached an equilibrium in which no-till is used on some types of land or with some crops but not others. Although our study provides strong evidence of the effect of land and climate conditions on no-till use, it does not speak to the role of crop choice. Studies indicate that farmers rotate tillage practices along with crops (Reimer, Weinkauf, and Prokopy, 2012), particularly corn and soybeans, and our data do suggest no-till is more likely for soybeans than for corn. A logical next step is to create a panel using the ARMS cropping and tillage history data and test the extent to which crop and tillage choice decisions are made jointly.

Another possibility is that producers using ANT are in transition from CT to CNT. It is unlikely that farmers who have never used no-till will adopt it on $100 \%$ of their crop acreage in a single year. Further, the initial transition to notill may present issues with weed management (Hobbs, 2007). Farmers may also use no-till for several years but then till if they experience challenges with weed management (Shrestha et al., 2006). It may take some time before farmers learn to adequately manage pests with no-till production. Regardless of the reason, if no-till is alternated with other tillage practices, the full public and private benefits of no-till may never be realized. Unfortunately, the farm-level dynamics of no-till use are difficult to study because our data (and all other available data) provide a snapshot of field-level no-till adoption over a relatively short period of years.

Future research may also consider constructing panels, using more years of no-till choice data, and incorporating other farmer attributes such as attitudes toward conservation, stewardship, whether the farmer received no-till payments, and other characteristics that may help explain what motivates farmers to transition into CNT. In addition, farmers make decisions to till before each planting season. Weather, soil moisture, temperature, nutrient needs, equipment availability, and issues with suppliers are some of the factors considered at the beginning of each season that could lend insight into the challenges that farmers face with sustained adoption. 


\section{Supplementary material}

To view supplementary material for this article, please visit https://doi.org/10. 1017/aae.2016.48

\section{References}

Auffhammer, M., S. Hsiang, W. Schlenker, and A. Sobel. "Using Weather Data and Climate Model Output in Economic Analyses of Climate Change." Review of Environmental Economics and Policy 7,2(2013):181-98.

Baumgart-Getz, A., L.S. Prokopy, and K. Floress. "Why Farmers Adopt Best Management Practice in the United States: A Meta-Analysis of the Adoption Literature." Journal of Environmental Management 96,1(2012):17-25.

Bergtold, J., and J. Molnar. "Limited Access to Conservation: Limited-Resource Farmer Participation in the Conservation Security Program in the Southeast." Journal of Agricultural and Applied Economics 42,2(2010):211-27.

Bullock, D.G. "Crop Rotation." Critical Reviews in Plant Sciences 11,4(1992):309-26.

Cameron, A.C., and P.K. Trivedi. Microeconomics Methods and Applications. New York: Cambridge University Press, 2005.

Davey, K., and W.H. Furtan. "Factors That Affect the Adoption Decision of Conservation Tillage in the Prairie Region of Canada." Canadian Journal of Agricultural Economics $56,3(2008): 257-75$.

De La Torre Ugarte, D., C. Hellwinckel, and J. Larson. "Enhancing Agriculture's Potential to Sequester Carbon: A Framework to Estimate Incentive Levels for Reduced Tillage." Environmental Management 33,S1(2004):S229-37.

D'Emden, F.H., R.S. Llewellyn, and M.P. Burton. "Factors Influencing Adoption of Conservation Tillage in Australian Cropping Regions." Australian Journal of Agricultural and Resource Economics 52,2(2008):169-82.

Ding, Y., K. Schoengold, and T. Tadesse. "The Impact of Weather Extremes on Agricultural Production Methods: Does Drought Increase Adoption of Conservation Practices?” Journal of Agricultural and Resource Economics 34,3(2009):395-411.

Dobos, R.R., H.R. Sinclair, and M.P. Robotham. User Guide for the National Commodity Crop Productivity Index (NCCPI). Version. 2.0. Lincoln, NE: U.S. Department of Agriculture, Natural Resources Conservation Service, National Soil Survey Center, 2012.

Fernandez-Cornejo, J., C. Hallahan, R. Nehring, S. Wechsler, and A. Grube. "Conservation Tillage, Herbicide Use, and Genetically Engineered Crops in the United States: The Case of Soybeans." AgBioForum 15,3(2012): 231-41.

Gould, B.W., W.E. Saupe, and R.M. Kleeme. "Conservation Tillage: The Role of Farm and Operator Characteristics and the Perception of Soil Erosion." Land Economics $65,2(1989): 167-82$.

Hobbs, P.R. "Conservation Agriculture: What Is It and Why Is It Important for Future Sustainable Food Production?” Journal of Agricultural Science 145,2(2007):127-37.

Hoppe, R., and J. MacDonald. Updating the ERS Farm Typology. Washington, DC: U.S. Department of Agriculture, Economic Research Service, Information Bulletin No. 110, 2013. 
Horowitz, J., R. Ebel, and K. Ueda. “No-Till” Farming Is a Growing Practice. Washington, DC: U.S. Department of Agriculture, Economic Research Service, Information Bulletin No. 70, 2010.

Johnson, J.M.F., D.C. Reicosky, R.R. Allmaras, T.J. Sauer, R.T. Venterea, and C.J. Dell. "Greenhouse Gas Contributions and Mitigation Potential of Agriculture in the Central USA." Soil and Tillage Research 83,1(2005):73-94.

Knowler, D., and B. Bradshaw. "Farmers' Adoption of Conservation Agriculture: A Review and Synthesis of Recent Research." Food Policy 32,1(2007):25-48.

Kumar, S., A. Kadono, R. Lal, and W. Dick. "Long-Term No-Till Impacts on Organic Carbon and Properties of Two Contrasting Soils and Corn Yields in Ohio." Soil Science Society of America Journal 76,5(2012):1798-809.

Kurkalova, L., C. Kling, and J. Zhao. "Green Subsidies in Agriculture: Estimating the Adoption Costs of Conservation Tillage from Observed Behavior." Canadian Journal of Agricultural Economics 54,2(2006):247-67.

Lambert, D.M., P. Sullivan, R. Claassen, and L. Foreman. "Profiles of US Farm Households Adopting Conservation-Compatible Practices." Land Use Policy 24,1(2007):7288.

Lichtenberg, E., J. Shortle, J. Wilen, and D. Zilberman. "Natural Resource Economics and Conservation: Contributions of Agricultural Economists." American Journal of Agricultural Economics 92,2(2010):469-86.

Mezzatesta, M., D. Newburn, and R. Woodard. "Additionality and the Adoption of Farm Conservation Practices." Land Economics 89,4(2013):722-42.

Ogle, S.M., A. Swan, and K. Paustian. "No-Till Management Impacts on Crop Productivity, Carbon Input and Soil Carbon Sequestration." Agriculture, Ecosystems \& Environment 149,1(2012):37-49.

Pautsch, G., L. Kurkalova, B. Babcock, and C. Kling. "The Efficiency of Sequestering Carbon in Agricultural Soils." Contemporary Economic Policy 19,2(2001):123-34.

Perry, E., G. Moschini, and D. Hennessy. "Testing for Complementarity: Glyphosate Tolerant Soybeans and Conservation Tillage." American Journal of Agricultural Economics 98,3(2016):765-84.

Prokopy, L.S., K. Floress, D. Klotthor-Weinkauf, and A. Baumgart-Getz. "Determinants of Agricultural Best Management Practice Adoption: Evidence from the Literature." Journal of Soil and Water Conservation 63,5(2008):300-311.

Rahm, M.R., and W.E. Huffman. "The Adoption of Reduced Tillage: The Role of Human Capital and Other Variables." American Journal of Agricultural Economics 66,4(1984):405-13.

Reimer, A.P., D.K. Weinkauf, and L.S. Prokopy. "The Influence of Perceptions of Practice Characteristics: An Examination of Agricultural Best Management Practice Adoption in Two Indiana Watersheds.” Journal of Rural Studies 28,1(2012):118-28.

Robertson, G.P., K.L. Gross, S.K. Hamilton, D.A. Landis, T.M. Schmidt, S.S. Snapp, and S.M. Swinton. "Farming for Ecosystem Services: An Ecological Approach to Production Agriculture." BioScience 64,5(2014):404-15.

Schoengold, K., Y. Ding, and R. Headlee. "The Impact of Ad Hoc Disaster Crop Insurance Programs on the Use of Risk-Reducing Conservation Tillage Practices." American Journal of Agricultural Economics 97,3(2015):897-919.

Secchi, S., P.W. Gassman, J.R. Williams, and B.A. Babcock. "Corn-Based Ethanol Production and Environmental Quality: A Case for Iowa and the Conservation Reserve Program." Environmental Management 44,4(2009):732-44. 
Shrestha, A., T. Lanini, S. Wright, R. Vargas, and J. Mitchell. Conservation Tillage and Weed Management. Oakland: Division of Agricultural and Natural Resources, University of California, Publication 8200, 2006.

Soane, B.D., B.C. Ball, J. Arvidsson, G. Basch, F. Moreno, and J. Roger-Estrade. "NoTill in Northern, Western and South-Western Europe: A Review of Problems and Opportunities for Crop Production and the Environment." Soil and Tillage Research 118(2012):66-87.

Soule, M.J. "Soil Management and the Farm Typology: Do Small Family Farms Manage Soil and Nutrient Resources Differently Than Large Family Farms?" Agricultural and Resource Economics Review 30,2(2001):179-88.

Soule, M., A. Tegene, and K. Wiebe. "Land Tenure and the Adoption of Conservation Practices." American Journal of Agricultural Economics 82,4(2000):9931005.

Toliver, D.K., J.A. Larson, R.K. Roberts, B.C. English, D.G. De La Torre Ugarte, and T.O. West. "Effects of No-Till on Yields as Influenced by Crop and Environmental Factors." Agronomy Journal 104,2(2012):530-41.

Triplett, G.B., and W.A. Dick. "No-Tillage Crop Production: A Revolution in Agriculture!" Agronomy Journal 100,S3 (2008):S-153-65.

Uri, N.D. "Perceptions on the Use of No-Till Farming in Production Agriculture in the United States: An Analysis of Survey Results." Agriculture, Ecosystems, and Environment 77,3(2000):263-66.

U.S. Department of Agriculture, Economic Research Service (UDSA-ERS). Farm Resource Regions. Washington, DC: USDA-ERS, Information Bulletin No. 760, 2000. Internet site: http://ageconsearch.umn.edu/bitstream/33625/1/ai000760.pdf (Accessed October 24, 2013).

—. "Data Products." Internet site: https://www.ers.usda.gov/data-products/ (Accessed February 7, 2017).

U.S. Department of Agriculture, National Agricultural Statistical Service (USDA-NASS). Field Crops Usual Planting and Harvesting Dates. Washington, DC: UDSA-NASS, Agricultural Handbook No. 628, 2010.

U.S. Department of Agriculture, Natural Resources Conservation Service (USDA-NRCS). Soil Health Literature Summary-Effects of Conservation Practices on Soil Properties in Areas of Cropland. Washington, DC: USDA-NRCS, National Soil Survey Center, 2015. Internet site: http://www.nrcs.usda.gov/wps/portal/nrcs/detailfull/soils/health/ mgnt/?cid=stelprdb1257753 (Accessed February 7, 2017).

Wade, T., R. Claassen, and S. Wallander. Conservation-Practice Adoption Rates Vary Widely by Crop and Region. Washington, DC: U.S. Department of Agriculture, Economic Research Service, Information Bulletin No. 147, 2015.

Wade, T., L. Kurkalova, and S. Secchi. "Modeling Field-Level Conservation Tillage Adoption with Aggregate Choice Data." Journal of Agricultural and Resource Economics 41,2(2016):266-85.

Wang, H.H., D.L. Young, and O.M. Camara. "The Role of Environmental Education in Predicting Adoption of Wind Erosion Control Practices." Journal of Agricultural and Resource Economics 25,2(2000):547-58.

West, T.O., and W.M. Post. "Soil Organic Carbon Sequestration Rates by Tillage and Crop Rotation." Soil Science Society of America Journal 66,6(2002):1930-46.

Wilman, E. "Carbon Sequestration in Agricultural Soils." Journal of Agricultural and Resource Economics 36,1(2011):121-38. 
Wu, J., R. Adams, C. Kling, and K. Tanaka. "From Microlevel Decisions to Landscape Changes: An Assessment of Agricultural Conservation Policies." American Journal of Agricultural Economics 86,1(2004):26-41.

Wu, J., and B.A. Babcock. "The Choice of Tillage, Rotation, and Soil Testing Practices: Economic and Environmental Implications." American Journal of Agricultural Economics 80,3(1998):494-511.

Yang, W., C. Sheng, and P. Voroney. "Spatial Targeting of Conservation Tillage to Improve Water Quality and Carbon Retention Benefits." Canadian Journal of Agricultural Economics 53,4(2005):477-500.

Yin, X., and M.M. Al-Kaisi. "Periodic Response of Soybean Yields and Economic Returns to Long-Term No-Tillage.” Agronomy Journal 96,3(2004):723-33. 